\title{
Correction: Disease candidate gene identification and prioritization using protein interaction networks Jing Chen ${ }^{1,2}$, Bruce J Aronow ${ }^{1,2,3}$ and Anil G Jegga ${ }^{1,3}$
}

Addresses: ${ }^{1}$ Division of Biomedical Informatics, Cincinnati Children's Hospital Medical Center, Cincinnati, USA, ${ }^{2}$ Department of Biomedical Engineering, University of Cincinnati, Cincinnati, USA and ${ }^{3}$ Department of Pediatrics, University of Cincinnati College of Medicine, Cincinnati, USA

E-mail: Jing Chen - chej1@mail.uc.edu; Bruce J Aronow - Bruce.Aronow@cchmc.org; Anil G Jegga* - Anil.Jegga@cchmc.org

${ }^{*}$ Corresponding author

Published: 9 December 2009

BMC Bioinformatics 2009, 10:406 doi: 10.1/86/I47|-2105-10-406
Received: 26 November 2009

Accepted: 9 December 2009

This article is available from: http://www.biomedcentral.com/I47I-2/05/10/406

(c) 2009 Chen et al; licensee BioMed Central Ltd.

This is an Open Access article distributed under the terms of the Creative Commons Attribution License (http://creativecommons.org/licenses/by/2.0), which permits unrestricted use, distribution, and reproduction in any medium, provided the original work is properly cited.

\section{Text}

After the publication of this work [1], we became aware of the fact that we inadvertently failed to include the work of Chen et al. [2] when listing previous studies that use PPIs to prioritize disease candidate genes. In a pioneering study [2], Chen et al. used a initial gene list for Alzheimer's from the OMIM database, expanded it based on protein interactions, and proposed a scoring function to identify other Alzheimer's disease causal genes based on graph-connectedness.

\section{References}

I. Chen J, Aronow BJ and Jegga AG: Disease candidate gene identification and prioritization using protein interaction networks. BMC Bioinformatics 2009, 10:73.

2. Chen JY, Shen $C$ and Sivachenko AY: Mining Alzheimer disease relevant proteins from integrated protein interactome data. Pac Symp Biocomput 2006, 367-378.
Publish with BioMed Central and every scientist can read your work free of charge

"BioMed Central will be the most significant development for disseminating the results of biomedical research in our lifetime. "

Sir Paul Nurse, Cancer Research UK

Your research papers will be:

- available free of charge to the entire biomedical community

- peer reviewed and published immediately upon acceptance

- cited in PubMed and archived on PubMed Central

- yours - you keep the copyright

Submit your manuscript here:

http://www.biomedcentral.com/info/publishing_adv.asp
BioMedcentral 